Wahyu Tri Astuti, Sapta Sari Dewi

Penerapan Fisioterapi Dada Terhadap Status Respirasi Pada An. A Dengan Bronkopneumonia

\title{
Penerapan Fisioterapi Dada Terhadap Status Respirasi Pada An. A Dengan Bronkopneumonia
}

\author{
Wahyu Tri Astuti ${ }^{1}$, Sapta Sari Dewi ${ }^{2}$ \\ ${ }^{1), 2)}$ Akademi Keperawatan Karya Bhakti Nusantara Magelang
}

Korespondensi penulis: astuti.wahyutri@yahoo.co.id

\begin{abstract}
Abstrak
Pada pasien bronkopneumonia menunjukkan sesak nafas dengan repirasi rate tidak normal dan dahak yang susah dikeluarkan, maka perlu dilakukan penatalaksanaan dengan farmakologi dan non farmakologi. Pada non farmakologi salah satunya dengan tindakan fisioterapi dada. Tujuan studi kasus ini adalah untuk mengetahui status respirasi dan pengeluaran sputum sebelum dan sesudah tindakan. Metode studi kasus ini ada deskriptif kualitatif dengan pendekatan studi kasus bronkopneumonia di ruang Multazam Rumah Sakit PKU Muhammadiyah Temanggung. Setelah dilakukan tindakan fisioterapi dada selama 3 hari didapatkan hasil terjadi pengeluaran sputum dan respirasi rate menurun. Rekomendasi untuk untuk Ny. V untuk selalu memperhatikan lingkungan An. A, jauhkan An. A dari asap kendaraan bermotor, debu juga asap rokok dan etika timbul gejala berulang hendaknya Ny. V bisa melakukan fisioterapi dada secara mandiri.
\end{abstract}

Kata kunci: bronkopneumonia; fisioterapi dada anak; pengeluaran sputum; status respirasi

\section{PENDAHULUAN}

Bronkopneumonia adalah suatu peradangan pada paru-paru yang mengenai satu atau beberapa lobus paru, yang ditandai dengan bercakbercak infiltrate yang disebabkan oleh Streptococus pneumococcus (30-5-\% kasus) dan diikuti oleh Staphylococcus aerus dan Klesiela pneumonia pada kasus yang lebih berat (Kartasasmita, 2010).

Gejala yang sering muncul pada pasien bronkopneumonia yaitu demam tinggi, gelisah, sesak nafas, nafas cepat dan dangkal (terdengar adanya bunyi ronchi), muntah, batuk kering dan produktif. Infeksi saluran pernafasan menyebabkan reaksi inflamasi yang dapat meningkatkan produksi sekret berlebih (Potter \& Perry, 2010).

Anak yang mengalami batuk berdahak sering terjadi peningkatan produksi lendir yang berlebihan pada paru-paru, Lendir tersebut sering menumpuk dan menjadi kental sehingga sulit untuk dikeluarkan (Kartasasmita, 2010). Terganggunya transportasi pengeluaran dahak ini dapat menyebabkan penderita semakin sulit untuk mengeluarkan dahaknya. Kemampuan anak mengeluarkan sputum dipengaruhi beberapa faktor diantaranya usia. Anak-anak pada umumnya belum bisa mengeluarkan dahak atau sputum dengan sendiri. Sputum dapat dikeluarkan dengan pemberian terapi mukolitik, ekspektoran, dan inhalasi (Hidayati, 2014). Penatalaksanaan yang biasa dilakukan pada anak dengan bronkopneumonia adalah dengan terapi farmakologi dan non 
farmakologi. Anak yang sudah mendapatkan terapi inhalasi akan mendapatkan tindakan fisioterapi dada. Fisioterapi dada merupakan suatu tindakan postural drainage, perkusi dan vibrasi pada bagian dada yang merupakan metode untuk memperbesar upaya klien dan memperbaiki fungsi paru-paru (Jauhar, 2013). Tujuan dari fisioterapi dada adalah membuang sekresi bronkhial, memperbaiki ventilasi, dan juga meningkatkan efisiensi pada otot-otot pernafasan (Muttaqin, 2010).

Penelitian yang dilakukan oleh Maidartati (2014) dengan judul pengaruh fisioterapi dada terhadap bersihan jalan nafas pada anak usia 1-6 tahun yang mengalami gangguan bersihan jalan nafas di Puskesmas Moch. Ramadhan Bandung didapatkan sampel penelitian kurang lebih sebanyak 11 anak, rata-rata usia anak 6 tahun dan penyakit terbanyak yang diderita adalah TB Paru sebanyak 6 orang $(54,5 \%)$. Anak yang mengeluarkan sputum sebelum fisioterapi dada sebanyak 8 orang, dan setelah fisioterapi dada pengeluaran sputum terjadi pada 11 anak $(100 \%)$. Hasil analisa bivariat terlihat nilai $p$ Value $0,000<\alpha 0,025$ maka dapat disimpulkan bahwa pengeluaran sputum sebelum dan sesudah fisioterapi dada relatif tidak sama atau fisioterapi dada efektif dalam mengeluarkan sputum.

Berdasarkan

kenyataan

dilapangan masih sering kita jumpai bahwa asuhan keperawatan pada pasien bronkopneumonia lebih banyak difokuskan pada tindakan kolaborasi dan farmakologi berupa pemberian obat nebulizer dan pemberian oksigen, tidak jarang masih banyak pula penderita bronkopneumonia yang belum mengetahui tentang terapi fisioterapi dada yang juga bisa dilakukan dirumah secara mandiri. Tujuan karya ilmiah ini adalah untuk mengetahui hasil penerapan pemberian fisioterapi dada terhadap pengeluaran sputum pada anak dengan bronkhopneumona.

\section{METODE}

Karya ilmiah ini menggunakan desain penelitian menggunakan pendekatan penelitian kualitatif dengan strategi penelitian case study reseach yaitu metode untuk menyelidiki, mempelajari kejadian seseorang yang dilakukan secara integrative, komprehensive agar memperoleh pemahaman tentang individu dan masalahnya bertujuan agar masalah dapat terselesaikan. Karya ilmiah ini berfokus pada pengeluaran sputum pada tindakan fisioterapi dada terhadap status respirasi pada An. A dengan bronkopneumonia di Ruang Multazam RS PKU Muhammadiyah Temanggung.

Subyek penelitian ini adalah An. A yang berusia 1 tahun lebih 3 bulan dengan bronkopneumonia dengan tanda batuk berdahak yang susah dikeluarkan, sesak nafas dengan respirasi 56 kali per menit dan gelisah. Pelaksanaan pengambilan kasus telah dilakukan pada tanggal 25 Maret 2019 sampai dengan tanggal 27 Maret 2019 di Ruang Multazam RS PKU Muhammadiyah Temanggung.

Uji keabsahan data menggunakan klien sebagai subyek A1, ibu klien sebagai subyek A2, dan perawat disebut subyek $\mathrm{P}$ sebagai sumber informasi. Analisa data penelitian studi kasus keperawatan yang digunakan adalah domain analisis, bertujuan untuk memperoleh gambaran tentang fisioterapi dada 
pada anak dengan bronkopneumonia yang bersifat umum tentang apa yang tercakup dalam fokus penelitian. Hasilnya untuk membantu pengeluaran sputum dengan mengamati pengeluaran dan karakteristik sputum sebelum dan sesudah fisioterapi dada.

\section{HASIL DAN PEMBAHASAN}

Sampel karya ilmiah ini terbagi atas subyek A dan B. Subyek A adalah An. A, usia 1 tahun lebih 3 bulan, riwayat kesehatan An. A yaitu : Ibu An. A mengatakan sebelumnya An. A belum pernah dirawat di rumah sakit. Sakit yang pernah diderita hanya batuk pilek dan demam biasa yang bisa sembuh dengan pemberian ASI yang banyak, tubuh anak dibalur dengan minyak telon dan dijaga agar tubuhnya tetap hangat. Awal mula dirawat di rumah sakit karena 4 hari sebelumnya An. A demam, batuk berdahak yang susah dikeluarkan, sesak nafas, pilek, dan muntah setelah minum ASI.

Subyek B adalah Ny. V, usia 29 tahun, agama Islam, pendidikan SMA, pekerjaan Ibu Rumah Tangga, Ny. V merupakan ibu dari Subyek A1. Wawancara dengan subyek A2 dilakukan tanggal 25 Maret 2019 pukul 08.00. Subyek A2 mengatakan sejak 4 hari yang lalu anaknya batuk berdahak yang susah dikeluarkan, sesak nafas, pilek, demam juga muntah setelah disusui dan didiagnosa oleh dokter bronkopneumonia.

Pengeluaran sputum sebelum dilakukan fisioterapi dada yaitu hasil wawancara dengan informan subyek A2 didapatkan data bahwa sputum banyak, susah dikeluarkan dan tidak tahu bagaimana cara mengeluarkannya sehingga membuat An. A rewel dan kesulitan bernafas. Sebagaimana yang diungkapkan dari kutipan hasil wawancara berikut :

"Batuknya ada dahaknya banyak mbak, kasihan rewel, susah nafas karena tidak bisa keluar, saya juga tidak tau bagaimana cara mengeluarkannya." (A2 2224)

Triangulasi hasil wawancara dengan informan subyek $P$ mendapatkan hasil bahwa subyek A2 belum mengetahui bagaimana cara mengeluarkan sputum. Hal tersebut dapat dilihat dari hasil wawancara antara peneliti dengan subyek A2 sebagai berikut :

"Kalau saya tanya ibu An. A ini belum tau bagaimana caranya mengeluarkan sputumnya mbak" (P 31-32)

Berdasarkan hasil wawancara dengan ibu subyek A2 didapatkan hasil awal mula terjadi produksi sputum berlebih saat batuk muncul. Sebagaimana seperti yang diungkapkan pada wawancara berikut;

"Mulainya semua ini ya 4 hari yang lalu mbak, batuk berdahak, banyak sekali dahaknya" (A2 15-16)

Adapun hasil triangulasi wawancara antara peneliti dengan subyek $\mathrm{P}$ bahwa menurut pengakuan subyek A2 kepada subyek P, sputum berlebih ada sejak 4 hari yang lalu. Berikut kutipan percakapannya :

"Ini sputum berlebihnya sekitar 4 hari yang lalu mbak." (P 27-28)

Anak yang mengalami gangguan saluran pernafasan sering terjadi peningkatan lendir yang berlebihan pada paru-parunya, sputum sering menumpuk dan menjadi 
Wahyu Tri Astuti, Sapta Sari Dewi

Penerapan Fisioterapi Dada Terhadap Status Respirasi Pada An. A Dengan Bronkopneumonia

kental sehingga sulit untuk dikeluarkan, Terganggunya transportasi pengeluaran dahak ini dapat menyebaban penderita semakin kesulitan untuk mengeluarkan dahaknya. Kemampuan anak mengeluarkan sputum dipengaruhi beberapa faktor diantaranya usia, seperti halnya yang terjadi pada An. A tersebut. Anak-anak pada umumnya belum bisa mengeluarkan dahak atau sputum dengan sendiri oleh sebab itu untuk mempermudah hal tersebut dapat dibantu salah satunya dengan cara fisioterapi dada.

Sebelum dilakukan fisioterapi dada anak gelisah dan menangis karena sputum susah dikeluarkan. Hal tersebut selaras dengan yang disampaikan oleh para ahli yang mengatakan Anak yang mengalami batuk berdahak sering terjadi peningkatan produksi lendir yang berlebihan pada paru-paru, lendir tersebut sering menumpuk dan menjadi kental sehingga sulit untuk dikeluarkan (Kartasasmita, 2010).

Terganggunya transportasi pengeluaran dahak ini dapat menyebabkan penderita semakin sulit untuk mengeluarkan dahaknya. Kemampuan anak mengeluarkan sputum dipengaruhi beberapa faktor diantaranya usia. Anak-anak pada umumnya belum bisa mengeluarkan dahak atau sputum dengan sendiri. Sputum dapat dikeluarkan dengan pemberian terapi mukolitik, ekspektoran, dan inhalasi (Hidayati, 2014).

Pengeluaran sputum setelah fisioterapi dada didapatkan produksi sputum yang berlebih setelah dilakukan fisioterapi dada pada hari pertama tanggal 25 Maret 2019 menunjukkan adanya pengeluaran sputum berwana putih kekuningan dan kental keluar bersamaan dengan muntah. Hal tersebut ditunjukkan pada wawancara berikut :

"Wah muntah mbak, tapi kok tidak hanya susu tapi ada dahaknya kental warna putih kekuningan seperti itu ya." (A 129-130)

Adapun hasil triangulasi perawat juga menyebutkan bahwa sputum yang keluar bersama dengan muntah yaitu sputum yang kental berwarna putih kekuningan. Seperti pada wawancara berikut :

"Ya mbak muntah dengan dahak kental berwarna putih kekuningan." (P 67-68)

Pada hari kedua tanggal 26 Maret 2019 terjadi penurunan produksi sputum pada An. A dapat diartikan dengan dahak tidak sebanyak sebelumnya setelah dilakukan fisioterapi dada menurut pengakuan subyek A2 sebagaimana yang ada pada wawancara berikut ini :

"Dahaknya juga tidak sebanyak sebelumnya." (A2 63-64)

Hasil wawancara terhadap informan subyek $\mathrm{P}$ dengan peneliti mendapatkan hasil triangulasi bahwa sputum sudah sebanyak kemarin. Berikut kutipan wawancaranya :

"Kalau tadi memang sputumnya sudah tidak sebanyak kemarin ya mbak." (P 77-78)

Pada hari ketiga tanggal 27 Maret 2019 produksi sputum An. A sudah menurun, tidak sebanyak saat pertama kali opname. Hal tersebut dibuktikan dengan hasil wawancara berikut :

"Dahaknya juga sudah tinggal sedikit kan mbak 
tidak seperti waktu pertama kali opname itu." (A2 243245)

$$
\begin{aligned}
& \text { Pada wawancara triangulasi } \\
& \text { peneliti dengan subyek P } \\
& \text { mengatakan sputum didalam sudah } \\
& \text { tidak banyak. Berikut } \\
& \text { wawancaranya: }
\end{aligned}
$$

"Sekret didalam juga sudah tidak banyak mbak." (P 9394)

Fisioterapi dada ini walaupun caranya terlihat sederhana tapi sangat efektif dalam upaya mengeluarkan sekret dan memperbaiki status respirasi pada An. A. Setelah dilakukan tindakan fisioterapi dada sputum bisa keluar sehingga menyebabkan status respirasi membaik karena An. A menagis dan muntah yang disertai dengan keluarnya sputum. Hal ini selaras dengan yang disampaikan oleh Betz dan Sowden (2002) bahwa beberapa faktor yang menyebabkan anak tidak bisa mengeluarkan sputumnya sendiri salah satunya adalah karena faktor usia. Pada anak dengan usia yang masih dini tentu belum bisa melakukan batuk efektif untuk mengeluarkan sputum, maka mereka hanya bisa mengeluarkan sputum. Bersamaan dengan muntah

\section{KESIMPULAN}

Hasil dari pemberian tindakan fisioterapi dada pada hari pertama sudah menunjukan penurunan respirasi dari 56 menjadi 50 kali per menit dan keluarnya sputum kental putih kekuningan, di hari kedua respirasi kembali turun yang awalnya 46 kali per menit menjadi 44 kali per menit, sputum kental berwarna putih kekuningan keluar dan pada hari ketiga respirasi sudah normal yaitu 36 kali per menit, pasien tidak menangis, tidak muntah dan tidak mengeluarkan sputum.

Perawat dapat merekomendasikan kepada ibu untuk selalu memperhatikan kondisi lingkungan saat berada di rumah, menjauhkan anak dari asap kendaraan bermotor, debu juga asap rokok. Perawat juga perlu memberikan pelatihan kepada ibu tentang tindakan fisioterapi dada kepada anak agar apabila muncul gejala berulang, diharapkan ibu mampu melakukan fisioterapi dada secara mandiri di rumah.

\section{DAFTAR PUSTAKA}

Arifiana \& Lusiana, A. (2016). Asuhan Neonatus Bayi dan Anak Pra Sekolah. Yogyakarta: Transmedika.

Bararah, T dan Jauhar, M. 2013. Asuhan Keperawatan

Panduan Lengkap Menjadi Perawat Profesional. Jakarta: Prestasi Pustakaraya.

Betz dan Sowden. (2002). Buku Saku Keperawatan Pediatari. Edisi 3. Alih Bahasa Tambayong. Jakarta: EGC

Marini, G. (2016). Efektifitas Fisioterapi Dada untuk Mengatasi Masalah Bersihan Jalan Nafas pada Anak dengan Bronkopneumonia Di Ruang Anak RSUD Dr. Moch Soewandi (Tidak Dipublikasikan). Skripsi: Stikes Muhammadiyah Gombong.

Kartasasmita, C. (2010). Pneumonia Pembunuh Balita. Buletin Jendela Epidemiologi, volume 3 . ISSN: 2087-1546.

Maidartati. (2014). Pengaruh 
Wahyu Tri Astuti, Sapta Sari Dewi

Penerapan Fisioterapi Dada Terhadap Status Respirasi Pada An. A Dengan Bronkopneumonia

Fisioterapi Dada Terhadap

Bersihan Jalan Nafas Pada

Anak Usia 1 sampai 6 Tahun

Yang Mengalami Gangguan

Bersihan Jalan Nafas Di

Puskesmas Moch. Ramadhan

Bandung.

Jurnal

keperawatan BSI, 2(1), DOI:

https://doi.org/10.31311/v21.

$\underline{140 .}$.

Marni. (2016). Asuhan Keperawatan Anak Pada Penyakit Tropis. Jakarta: Erlangga.

Muttaqin, Arif. (2008). Buku Ajar Asuhan Keperawatan Klien Dengan Gangguan Sistem Pernafasan. Jakarta: Salemba Medika.

Ngastiyah. (2009). Perawatan Anak Sakit. Edisi 2. Jakarta: EGC.

Potter, \& Perry. (2010). Fundamental of Nursing: Concept, Process and Practice. Edisi 7. Vol. 3. Jakarta: EGC. 